\title{
Management of sacrococcygeal pilonidal sinus disease in children: A survey study in Turkey
}

\author{
Anar Gurbanov(D), Ergun Ergün(D), Gülnur Göllü(D), Ufuk Ateş(D) \\ Division of Pediatric Surgery, Ankara University Facuty of Medicine, Ankara, Turkey
}

\begin{abstract}
Objective: Sacrococcygeal pilonidal sinus disease is common in children. The disease reduces the quality of life of patients with symptoms such as pain and chronic discharge. Variable surgical techniques have been described for the treatment of pilonidal sinus disease. This study aims to evaluate clinical approach of Turkish pediatric surgeons to children with pilonidal sinus disease.

Material and Methods: Survey questions were prepared through a literature review for controversial issues. The participants were asked pre-selected and checkbox questions. The survey was sent to 450 pediatric surgeons, members of the Association of Turkey Pediatric Surgery via a link to Google Forms.

Results: Nineteen percent (88) of the members responded. Seventy five (85.2\%) of the pediatric surgeons stated that they did not perform additional preoperative imaging. Surgical excision methods were preferred more than minimally invasive procedures (102 to 46$)$. Sixty (68.2\%) of the participants preferred preoperative prophylactic single dose intravenous antibiotics and postoperative oral antibiotics. Regarding the participants' practices, poor local hygiene, overweight, wide or deep sinus pit were stated as the most common causes of recurrence. Vast majority of the pediatric surgeons recommended laser epilation (\%85.2) and slimming (59.1\%) to patients.
\end{abstract}

Conclusion: Various studies have been published from Turkey for pilonidal sinus disease. As seen in the current study, Turkish pediatric surgeons do not have a common opinion in pilonidal sinus disease and prefer surgical excision methods more frequently. Prospective randomized studies with bigger number of patients are required to establish common guidelines in disease management.

Keywords: Pilonidal sinus, child, surveys and questionnaires

Cite this article as: Gurbanov A, Ergün E, Göllü G, Ateș $U$. Management of sacrococcygeal pilonidal sinus disease in children: A survey study in Turkey. Turk J Surg 2021; 37 (3): 260-265.

\section{Corresponding Author}

Ufuk Ateş

E-mail:drufukates@gmail.com

Received: 17.11 .2020

Accepted: 19.04 .202

Available Online Date: 28.09 .2021

o Copyright 2021 by Turkish Surgical Society Available online at www.turkjsurg.com

DOI: $10.47717 /$ turkjsurg.2021.5100

\section{INTRODUCTION}

Although it is not as common as it is in adult population, sacrococcygeal pilonidal sinus disease (PSD) is not very rare in children (1). The disease reduces the quality of life of patients with symptoms such as pain and chronic discharge (2). There are many different approaches to PSD management (3). Variable surgical techniques have been described for the treatment of PSD, and optimal choice remains controversial (4). The ideal treatment for PSD should lead to a cure with rapid recovery period and associated morbidity as low as possible especially in adolescents concerning the effects of longer time with disease at school and social life $(4,5)$. However, there is no ideal approach, and the treatment of the disease varies between centers (6). PSD is common in Turkish adolescents (7). The study aims to evaluate the clinical approach of Turkish pediatric surgeons to children with PSD.

\section{MATERIAL and METHODS}

The survey questions were prepared through a literature review for controversial issues in PSD treatment. The participants were asked pre-selected and checkbox questions about their demographic features, preoperative preparation, surgical techniques, approach to patients with different symptoms, postoperative advice and follow-up. The questionnaire was tested online among the authors before it was sent to the participants. The study was approved by the local ethical committee. The approval for the study was obtained from the clinical practices local ethics committee of the university in 13.07.2020 (No: 16-367-20). The survey was sent without excluding any members via a link to Google Forms. The survey was sent to the participants only once via e-mail and it was expected to be answered within a month. 


\section{RESULTS}

Eighty-eight members responded. The response rate of the participants was $19.5 \%$. Thirty-four (38.6\%) of them had more than 16 years of experience in pediatric surgery. Half of the participants (47.7\%) were working in university hospitals. The majority of the participants (72.8\%) stated that they treat an average of 0 to 20 pilonidal sinus patients annually. Only seven (8\%) surgeons stated that they treated 40 or more PSD patients annually. Demographic features of the participants are given in Table 1. Seventy five (85.2\%) of the pediatric surgeons stated that they did not perform additional preoperative imaging. The most (12.5\%) preferred imaging method was ultrasonography (USG). Eightyone of the participants (92.1\%) preferred surgical intervention when there could be no drainage. When the pediatric surgeons were asked about their preferred treatment methods, it was seen that surgical excision methods were preferred more than minimally invasive procedures (102 to 46). The most preferred surgical technique was "Excision and primary closure" (62.5\%). The most commonly applied of minimally invasive methods was "phenol injection" (34.1\%). It was seen that most of the participants did not routinely apply phenol repeatedly but only when the patient's complaints lasted. Detailed preoperative approaches are given in Table 2. In the approach to complicated patients (abscess developed and/or has a large defect and/or recurrent), surgical excision techniques (62.5\%) were preferred as the primary approach more than minimally invasive techniques. Thirty-four (38.6\%) of the participants suggested clinical follow-up for asymptomatic patients. In pediatric patients, it was seen that there was no surgical procedure without anesthesia for PSD and the most preferred method was general anesthesia (55.7\%). Sixty (68.2\%) of the participants preferred preoperative prophylactic single dose intravenous antibiotic and postoperative oral antibiotic in patients with PNS disease. Five participants (\%5.7) stated that they did not use antibiotics before or after the operation. Detailed intraoperative approaches are given in Table 3. Regarding the participants' practices, poor local hygiene, overweight, wide or deep sinus pit were stated as the most common causes of recurrence. The vast majority of pediatric surgeons recommended laser epilation (\%85.2) and slimming (59.1\%) to patients. Forty-two (47.7\%) of the participants stated that children needed 2-7 days for wound care after surgery, and 29 (33\%) participants stated that their patients returned to school or work within 8-14 days after intervention. Detailed postoperative approaches are given in Table 4.

\section{DISCUSSION}

The present study showed that there are many different approaches in PSD among the Turkish pediatric surgeons.

Majority of the participants in this study did not use preoperative imaging. Usually, complementary investigations are seldom needed because the diagnosis of pilonidal sinus disease is clinically easy (6). Nonetheless, x-ray imaging, sonography or magnetic resonance imaging are sometimes useful to eliminate anorectal fistula, or posterior anorectal tumor or sacral osteomyelitis (8-10). However, imaging methods such as ultrasonography and MRI play an important role in the planning and treatment of pilonidal sinus disease and helps to determine the prognosis of the disease $(11,12)$.

In this study, the participants preferred surgical excision methods more frequently than minimally invasive methods in the treatment of PSD. The most preferred surgical excision method was excision with primary midline closure followed by excision with secondary healing and 'excision with flap closure techniques, respectively.

In the literature, although there was no significant difference between primary closure and secondary healing techniques after excision in terms of length of hospitalization, duration of postoperative pain and recurrence rate, the recovery time of patients in the first group was significantly shorter $(5,13,14)$.

There is a limited number of child studies for "Excision with flap closure", and it is recommended to be used in complicated cases (15). However, it is emphasized that this method has a lower rate of recurrence compared to other excision methods $(16,17)$.

Table 1. Demographic features of the participants

\section{How many years have you been a pediatric surgeon?}

\begin{tabular}{|l|c|c|c|}
\hline $0-5$ years & $14(15.9 \%)$ & 6-10 years & $19(21.6 \%)$ \\
\hline $11-15$ years & $21(23.9 \%)$ & 16 and more years & $34(38.6 \%)$ \\
\hline Which institution do you work in? & & & \\
\hline Public hospital & $9(10.2 \%)$ & Education - research hospital & $26(29.5 \%)$ \\
\hline University hospital & $42(47.7 \%)$ & Private hospital & $11(12.5 \%)$ \\
\hline On average, how many pilonidal sinus patients do you treat per year? & $32(36.4 \%)$ & $10-20$ & $32(36.4 \%)$ \\
\hline $0-10$ & $6(6.8 \%)$ & $30-40$ & $11(12.5 \%)$ \\
\hline $20-30$ & $7(8 \%)$ & & \\
\hline 40 and more & & \\
\hline
\end{tabular}


Table 2. Preoperative approaches

\begin{tabular}{|c|c|c|c|}
\hline \multicolumn{4}{|l|}{ Preoperative imaging } \\
\hline No & $75(85.2 \%)$ & Sacral x-ray & $2(2.3 \%)$ \\
\hline Ultrasonography & $11(12.5 \%)$ & Computed tomography & $2(2.3 \%)$ \\
\hline Magnetic resonance tomography & $5(5.7 \%)$ & & \\
\hline \multicolumn{4}{|l|}{ Treatment options } \\
\hline Excision with primary midline closure & $55(62.5 \%)$ & Endoscopic treatment & $6(6.8 \%)$ \\
\hline Excision with secondary healing & $34(38.6 \%)$ & Conservative treatment & $4(4.5 \%)$ \\
\hline Excision with flap closure & $13(14.8 \%)$ & Aethoxysklerol treatment & $2(2.3 \%)$ \\
\hline Phenol treatment & $30(\% 34,1)$ & Microsinusectomy & $4(4.5 \%)$ \\
\hline \multicolumn{4}{|l|}{ Surgical method preferred reason } \\
\hline Surgical experience & $57(64.8 \%)$ & Minimally invasive & $30(34.1 \%)$ \\
\hline Low recurrence rate & $47(53.4 \%)$ & Other methods do not benefit & $13(14.8 \%)$ \\
\hline Short processing time & $20(22.7 \%)$ & Be reliable & $29(33 \%)$ \\
\hline \multicolumn{4}{|c|}{ How many times do you apply phenol in routine practice? (Total answers: 34 ) } \\
\hline For once & $9(26.5 \%)$ & Three times & $8(23.5 \%)$ \\
\hline Twice & $3(8.8 \%)$ & As the complaints repeat & $14(41.2 \%)$ \\
\hline \multicolumn{4}{|c|}{ If you apply phenol repeatedly, how often do you apply it? (Total answers: 30) } \\
\hline Weekly & $2(6.7 \%)$ & Monthly & $2(6.7 \%)$ \\
\hline Biweekly & $2(6.7 \%)$ & If recurrence develops & $20(66.7 \%)$ \\
\hline Every three weeks & $4(13.3 \%)$ & & \\
\hline
\end{tabular}

Although surgical excision techniques are used more frequently in the treatment of pilonidal sinus, invasive surgical techniques contain the risk of wound infection and require a long postoperative wound healing period (18).

In the last years, as in many areas of pediatric surgery, there is a tendency to turn towards minimally invasive methods in the treatment of pilonidal sinus disease $(19,20)$. It is thought that as the studies on the field of minimally invasive treatments increase, those who turn to this field will increase (21). In the current study, about one third of the participants stated that they used minimally invasive methods.

Among the minimally invasive methods, the most preferred one was phenol injection. Phenol injection is gaining popularity as a minimally invasive method in the treatment of PSD $(22,23)$. The method has started to be widely applied today because it can be performed daily, it is re-applicable, and applicable under local anesthesia and sedation. It also has the advantages of low surgical costs, low risk of postoperative infection and low need for postoperative wound care (18,24-26).

Two-thirds of the pediatric surgeons stated that they perform phenol injection only once and repeat the application only when recurrence occurs. Only ten participants routinely administered phenol injections; twice or more.

Even though it is not proven by randomized controlled studies, it has been stated that two or more phenol applications in PSD treatment have higher success rate than one-time phenol application $(27,28)$.

Forty percent of the participants who made more than one phenol injection in their routine practice stated that they repeated the application every three weeks. Dogru O. recommends applying phenol injection three times with two-week intervals (29).

Minimally invasive methods are also useful in recurrent cases $(28,30)$. In recurrent cases, participants preferred surgical excision techniques more frequently.

In the current study, clinical follow-up and conservative treatment were the most preferred in the approach to asymptomatic cases. Doll D. et al. argue that prophylactic surgery will not benefit in asymptomatic cases, and follow-up will be sufficient (31).

\section{CONCLUSION}

Various studies have been published from Turkey for PSD. The vast majority of these studies are case series and introduction or comparing of the treatment methods, and there are limited studies such as review on disease management. As seen in the current study, Turkish pediatric surgeons do not have a common opinion in pilonidal sinus disease and prefer surgical excision methods more frequently. Prospective randomized studies with bigger number of patients are required to establish common guidelines in disease management. 
Table 3. Intraoperative approaches. IV - intravenous; AB - antibiotic

\section{Approach to complicated patients}

\begin{tabular}{|c|c|c|c|}
\hline Excision with primary midline closure & $26(29.5 \%)$ & Excision with flap closure & $19(21.6 \%)$ \\
\hline Excision with secondary intention healing & $10(11.4 \%)$ & Minimally invasive methods & $7(8 \%)$ \\
\hline \multicolumn{3}{|c|}{ Minimally invasive methods first, surgical excision if unsuccessful } & $26(29.5 \%)$ \\
\hline \multicolumn{4}{|l|}{ Approach to asymptomatic patients } \\
\hline Conservative treatment & $21(23.9 \%)$ & Surgical excision & $20(22.7 \%)$ \\
\hline Minimally invasive methods & $13(14.8 \%)$ & Clinical follow-up & $34(38.6 \%)$ \\
\hline \multicolumn{4}{|c|}{ Approach in patients with multiple pilonidal sinus pits or large sinus cavities } \\
\hline Surgical excision & $60(68.2 \%)$ & Minimally invasive methods & $28(31.8 \%)$ \\
\hline \multicolumn{4}{|l|}{ Anesthesia method } \\
\hline Without anesthesia & 0 & Regional - spinal anesthesia & $47(53.4 \%)$ \\
\hline Local anesthesia & $18(20.5 \%)$ & Intravenous sedation & $20(22.7 \%)$ \\
\hline \multicolumn{3}{|l|}{ General anesthesia } & $49(55.7 \%)$ \\
\hline \multicolumn{4}{|l|}{ Antibiotic therapy during surgery } \\
\hline Preoperative IV prophylaxis & $5(5.7 \%)$ & Postoperative oral antibiotic & $6(6.8 \%)$ \\
\hline IV prophylaxis and postoperative oral AB & $60(68.2 \%)$ & IV AB before and after surgery & $12(13.6 \%)$ \\
\hline \multicolumn{3}{|l|}{ I don't use antibiotics } & $5(5.7 \%)$ \\
\hline
\end{tabular}

\section{Table 4. Postoperative approaches}

\section{Postoperative recommendations}

\begin{tabular}{|l|l|l|l|}
\hline Laser hair removal & $78(88.5 \%)$ & Peroral antibiotic therapy & $34(38.6 \%)$ \\
\hline Do not lie back & $40(45.3 \%)$ & Slimming & $53(60.2 \%)$ \\
\hline Local treatment with antibiotics & $19(21.6 \%)$ & Negative pressure wound therapy & $11.1 \%)$ \\
\hline
\end{tabular}

\section{Wound care period after surgery}

\begin{tabular}{|l|l|l|l|l|l|l|l|l|l|}
\hline 1 day & $13(14.8 \%)$ & $2-7$ days & $42(47.7 \%)$ & $8-14$ days & $22(25 \%)$ & $15-21$ days & $5(5.7 \%)$ & 22 and more & $6(6.8 \%)$ \\
\hline
\end{tabular}

\section{Postoperative control}

First day after surgery

Monthly

Daily or weekly until the wound $33(37.5 \%)$

care need is over

Time back to school or work after surgery

\begin{tabular}{|l|l|l|l|l|l|l|l|l|l|}
\hline $1-2$ days & $14(15.9 \%)$ & $3-7$ days & $24(27.3 \%)$ & $8-14$ days & $29(33 \%)$ & $15-21$ days & $12(13.6 \%)$ & 22 and more & $9(10.2 \%)$ \\
\hline
\end{tabular}

\section{The most common cause of recurrence}

\begin{tabular}{|l|l|l|l|l|l|}
\hline Poor local hygiene & $68(77.3 \%)$ & Overweight & $58(65.9 \%)$ & Surgery technique & $47(53.4 \%)$ \\
\hline Large sinus cavities & $43(48.9 \%)$ & Prolonged sitting & $42(47.7 \%)$ & Preoperative abscess & $27(30.7 \%)$ \\
\hline Male sex & $25(28.4 \%)$ & Delayed treatment & $21(23.9 \%)$ & No AB postoperatively & $18(20.5 \%)$ \\
\hline Smoking & $9(10.2 \%)$ & High patient age & $8(9.1 \%)$ & & \\
\hline
\end{tabular}

Ethics Committee Approval: The study was obtained from Ankara University Human Researches Ethical Committee (Decision No: 16-367-20, Date: 13.07.2020)

Peer-review: Externally peer-reviewed.

Author Contributions: Concept - A.Q., E.E., U.A.; Design - A.Q., E.E.; Supervision - U.A., G.G.; Data Collection and/or Processing - A.Q., E.E.; Analysis and/ or Interpratation - G.G., U.A.; Literature Review - A.Q., E.E.; Writing Manuscript - U.A.; Critical Reviews - E.E., G.G., U.A.

Conflict of Interest: The authors declare that they have no conflict of interest.

Financial Disclosure: The authors declared that this study has received no financial support. 


\section{REFERENCES}

1. Fike FB, Mortellaro VE, Juang D, Ostlie DJ, Peter SDS. Experience with pilonidal disease in children. J Surg Res 2011; 170(1): 165-8. [CrossRef]

2. McCallum IJ, King PM, Bruce J. Healing by primary closure versus open healing after surgery for pilonidal sinus: systematic review and metaanalysis. BMJ 2008; 336(7649): 868-71. [CrossRef]

3. Stauffer VK, Luedi MM, KaufP, Schmid M, Diekmann Ö, Wieferich K, et al. Common surgical procedures in pilonidal sinus disease: a metaanalysis, merged data analysis, and comprehensive study on recurrence. Sci Rep 2018; 8(1): 1-28. [CrossRef]

4. Hardy EJO, Herrod PJ, Doleman B, Phillips HG, Ranat R, Lund JN. Surgical interventions for the treatment of sacrococcygeal pilonidal sinus disease in children: A systematic review and meta-analysis. J Pediatr Surg 2019; 54(11): 2222-33. [CrossRef]

5. Harries RL, Alqallaf A, Torkington J, Harding KG. Management of sacrococcygeal pilonidal sinus disease. Int Wound J 2019; 16(2): 370-8. [CrossRef]

6. De Parades V, Bouchard D, Janier M, Berger A. Pilonidal sinus disease. J Visc Surg 2013; 150(4): 237-47. [CrossRef]

7. Duman K, Girgin M, Harlak A. Prevalence of sacrococcygeal pilonidal disease in Turkey. Asian J Surg 2017; 40(6): 434-7. [CrossRef]

8. de Miguel Criado J, del Salto LG, Rivas PF, del Hoyo LFA, Velasco LG, de las Vacas MIDP, et al. MR imaging evaluation of perianal fistulas: spectrum of imaging features. Radiographics 2012; 32(1): 175-194. [CrossRef]

9. Marra B, Fantini C, Brusciano L, Sauchelli L, De Falco A, Rossetti G, et al. Management of sacrococcygeal chordoma mimicking a pilonidal sinus: report of a case. Int J Colorectal Dis 2005; 20(4): 388-9. [CrossRef]

10. Koutserimpas C, Nikitakis N, Skarpas A, Lada M, Papachristou E, Velimezis $G$. Epidural abscess imitating recurrent pilonidal sinus: a case report. G Chir 2007; 38(3): 135. [CrossRef]

11. Mentes O, Oysul A, Harlak A, Zeybek N, Kozak O, Tufan T. Ultrasonography accurately evaluates the dimension and shape of the pilonidal sinus. Clinics 2009; 64(3): 189-92. [CrossRef]

12. Tonolini M. Cancer in perianal fistulas. Imaging of Perianal Inflammatory Diseases. Milano: Springer. 2013:197-202. [CrossRef]

13. Ozcan R, Hüseynov M, Bakır AC, Emre S, Tütüncü C, Celayir S, et al. Which treatment modality for pediatric pilonidal sinus: Primary repair or secondary healing? Asian J Surg 2018; 41(5): 506-10. [CrossRef]

14. Kallis MP, Maloney C, Lipskar AM. Management of pilonidal disease. Curr Opin Pediatr 2018; 30(3): 411-6. [CrossRef]

15. Bicer S, Ozdamar MY. Surgical approach in pediatric patients with pilonidal sinus disease. Arch Basic Clin Res 2019; 1(1): 12-5. [CrossRef]

16. Afsarlar CE, Yilmaz E, Karaman A, et al. Treatment of adolescent pilonidal disease with a new modification to the Limberg flap: symmetrically rotated rhomboid excision and lateralization of the Limberg flap technique. J Pediatr Surg 2013; 48(8): 1744-9. [CrossRef]
17. Can MF, Sevinc MM, Yilmaz M. Comparison of Karydakis flap reconstruction versus primary midline closure in sacrococcygeal pilonidal disease: results of 200 military service members. Surg Today 2009; 39(7): 580-6. [CrossRef]

18. Yuksel ME. Pilonidal sinus disease can be treated with crystallized phenol using a simple three-step technique. Acta Dermatovenerol Alp Pannonica Adriat 2017; 26(1): 15-7. [CrossRef]

19. Rothenberg S, Bansal S. Principles of Minimally Invasive Surgery in Children. Pediatric Surgery: General Principles and Newborn Surgery. 2020:477-486. [CrossRef]

20. Kalaiselvan R, Bathla S, Allen W. Minimally invasive techniques in the management of pilonidal disease. Int J Colorectal Dis 2019; 34(4): 561-8. [CrossRef]

21. Andersson RE. Less invasive pilonidal sinus surgical procedures. Coloproctology 2019; 41: 117-20. [CrossRef]

22. Ates U, Ergun E, Gollu G, Sozduyar S, Kologlu M, Cakmak M, et al. Pilonidal sinus disease surgery in children: the first study to compare crystallized phenol application to primary excision and closure. J Pediatr Surg 2018; 53(3): 452-5. [CrossRef]

23. Cevik M, Dorterler ME, Abbasoglu L. Is conservative treatment an effective option for pilonidal sinus disease in children? Int Wound J 2018; 15(5): 840-4. [CrossRef]

24. Bayhan Z, Zeren S, Duzgun SA. Crystallized phenol application and modified Limberg flap procedure in treatment of pilonidal sinus disease: a comparative retrospective study. Asian J Surg 2016; 39: 172-7. [CrossRef]

25. Emiroglu M, Karaali C, Salimoglu S, Sert I, Ugurlu L, Aydin C. The effect of phenol concentration on the treatment of pilonidal sinus disease: early results of a prospective randomized study. Int Surg 2016; 101: 127-32. [CrossRef]

26. Girgin $M$, Kanat BH, Ayten R, Cetinkaya $Z$, Kanat $Z$, Bozdağ A, et al. Minimally invasive treatment of pilonidal disease: crystallized phenol and laser depilation. Int Surg 2013; 97(4): 288-92. [CrossRef]

27. Girgin $M, K a n a t B H$. The results of a one-time crystallized phenol application for pilonidal sinus disease. Indian J Surg 2014; 76(1): 17-20. [CrossRef]

28. Emiroglu M, Karaali C, Esin H, Akpınar G, Aydın C. Treatment of pilonidal disease by phenol application. Turk J Surg 2017; 33(1): 5. [CrossRef]

29. Dogru O, Camci C, Aygen E, Girgin M, Topuz O. Pilonidal Sinus treated with crystallized phenol. Dis Colon Rectum 2004; 47(11): 1934-8. [CrossRef]

30. Kaymakcioglu N, Yagci G, Simsek A, Unlu A, Tekin OF, Cetiner S, et al. Treatment of pilonidal sinus by phenol application and factors affecting the recurrence. Tech Coloproctol 2005; 9(1): 21-4. [CrossRef]

31. Doll D, Friederichs J, Düsel W, Fend F, Petersen S. Surgery for asymptomatic pilonidal sinus disease. Int J Colorectal Dis 2008; 23(9): 839-44. [CrossRef] 


\section{ORIJINAL ÇALIŞMA-ÖZET}

Turk J Surg 2021; 37 (3): 260-265

\section{Çocuklarda sakrokoksigeal pilonidal sinüs hastalığının yönetimi: Türkiye'de bir anket çalışması}

Anar Gurbanov, Ergun Ergün, Gülnur Göllü, Ufuk Ateş

Ankara Üniversitesi Tıp Fakültesi, Pediatrik Cerrahi Bilim Dalı, Ankara, Türkiye

\section{ÖZET}

Giriş ve Amaç: Sakrokoksigeal pilonidal sinüs hastalığı çocuklarda yaygındır. Bu hastalık ağrı ve kronik akıntı gibi semptomları ile hastaların yaşam kalitesini düşürür. Pilonidal sinüs hastalığının tedavisi için çeşitli cerrahi teknikler tarif edilmiştir. Bu çalışma Türk çocuk cerrahların pilonidal sinüs hastalığı olan çocuklara klinik yaklaşımlarını değerlendirmeyi amaçlamaktadır.

Gereç ve Yöntem: Anket soruları, tartışmalı konular için bir literatür taraması yoluyla hazırlandı. Katılımcılara önceden seçmeli ve onay kutulu sorlar soruldu. Anket, Türkiye Çocuk Cerrahisi Derneği üyesi 450 çocuk cerrahına Google Formlar bağlantısı üzerinden gönderildi.

Bulgular: Üyelerin \%19'u (88) ankete yanıt verdi. Çocuk cerrahlarının 75'i $(\% 85,2)$ ameliyat öncesi ek görüntüleme yapmadıklarını belirtti. Minimal invaziv işlemlere göre cerrahi eksizyon yöntemleri daha çok tercih edildi $(102-46)$. Katılımcıların 60' $(\% 68,2)$ preoperatif profilaktik tek doz intravenöz antibiyotik ve postoperatif oral antibiyotiği tercih etti. Katılımcılar kötü lokal hijyen, fazla kilo, geniş veya derin sinüs çukuru nüksün en yaygın nedenleri olarak belirtilmektedir. Çocuk cerrahlarının büyük çoğunluğu hastalara lazer epilasyon $(\% 85,2)$ ve zayıflama $(\% 59,1)$ önermişlerdir.

Sonuç: Pilonidal sinüs hastalığı için Türkiye'den çeşitli çalışmalar yayınlanmıştır. Bu çalışmada da görüldüğü gibi Türk pediatrik cerrahların pilonidal sinüs hastalığı konusunda ortak bir görüşü yoktur ve daha sık cerrahi eksizyon yöntemlerini tercih etmektedir. Hastalık yönetiminde ortak kılavuzlar oluşturmak için daha fazla sayıda hasta içeren prospektif randomize çalışmalara ihtiyaç vardır.

Anahtar Kelimeler: Pilonidal sinus, çocuk, anket

Doi: $10.47717 /$ turkjsurg.2021.5100 